\title{
KAJIAN KONSENTRASI INSEKTISIDA NABATI TERHADAP PERTUMBUHAN DAN HASIL TANAMAN KEDELAI [Glycine max (L.) Merill] VARIETAS ANJASMORO
}

\section{STUDY ON THE CONCENTRATION OF BOTANICAL INSECTICIDES ON THE GROWTH AND YIELD OF SOYBEAN /Glycine max (L.) Merrill] ANJASMORO VARIETY}

\author{
Anggita Kusuma Ningrum, Sartono Joko Santosa dan Sumarmi* \\ Fakultas Pertanian Universitas Slamet Riyadi, Surakarta, Indonesia \\ Email:felt.sumarmi@gmail.com \\ * Corresponding Author, Diterima: 4 Mei 2021, Direvisi: 1 Des. 2021, Disetujui: 6 Des. 2021
}

\begin{abstract}
One of the inhibiting factors for increasing soybean production is the presence of pests. This research was aimed to assess botanical insecticides on the growth and result of soybean [Glycine max (L) Merrill.] Anjasmoro variety. Research was conducted in Getas, Wonosalam, Demak, Central Java, which has an altitude of 100 meters asl (above sea level) and dark gray gromosol soil types, from July to October 2020. The method used was a randomized completely block design (RCBD) with a single factor. The kinds of treatment were: soursop leaf extract with a concentration $150 \mathrm{~g} \mathrm{~L}^{-1}, 300 \mathrm{~g} \mathrm{~L}^{-1}, 450 \mathrm{~g} \mathrm{~L}^{-1}$; tobacco leaf extract with concentration $150 \mathrm{~g} \mathrm{~L}^{-1}, 300 \mathrm{~g} \mathrm{~L}^{-1}, 450 \mathrm{~g} \mathrm{~L}^{-1}$; a combination of soursop leaf extract and tobacco $150 \mathrm{~g}$ $L^{-1}, 300 \mathrm{gL}^{-1}, 450 \mathrm{gL}^{-1}$. The results obtained showed that the concentration of botanical insecticides affects plant growth. It indicated some increase in several growth parameters. The most significant growth occured in the combination treatment of soursop leaf extract and tobacco leaf with concentration $450 \mathrm{~g} \mathrm{~L}^{-1}$. The results of measurements were $59.40 \mathrm{~cm}$ plant height, 11.73 leaves, 40.60 pods, 87.16 seeds, $11.04 \mathrm{~g}$ seed weight, and $16.80 \mathrm{~g}$ weight of 100 seeds. The output of the observation of the intensity of pest incursions showed that the effective treatment to suppress whitefly (Bemisia tabacii) incursions was a combination of soursop leaves and tobacco with a concentration of $450 \mathrm{~g} \mathrm{~L}^{-1}$. The results was obtained at observations at the age of 84 days after planting were $36.20 \%$.
\end{abstract}

Keywords: Botanical insecticide, soursop, soybeans, tobacco.

\begin{abstract}
ABSTRAK
Salah satu faktor penghambat peningkatan produksi kedelai yaitu adanya serangan hama. Penelitian ini bertujuan untuk mengkaji insektisida nabati terhadap pertumbuhan dan hasil pada tanaman kedelai [Glycine max (L) Merrill] varietas Anjasmoro. Penelitian dilaksanakan di Desa Getas, Kecamatan Wonosalam, Kabupaten Demak, Jawa Tengah, dengan ketinggian tempat $100 \mathrm{~m}$ dpl (meter di atas permukaan laut) dan jenis tanah gromosol kelabu tua, Juli sampai dengan Oktober 2020. Rancangan yang digunakan adalah Rancangan Acak Kelompok Lengkap (RAKL) dengan faktor tunggal. Adapun macam perlakuannya yaitu: ekstrak daun sirsak dengan konsentrasi $150 \mathrm{~g} \mathrm{~L}^{-1}, 300 \mathrm{~g} \mathrm{~L}^{-1}, 450 \mathrm{~g} \mathrm{~L}^{-1}$; ekstrak daun tembakau dengan konsentrasi $150 \mathrm{~g} \mathrm{~L}^{-1}, 300 \mathrm{~g} \mathrm{~L}^{-1}, 450 \mathrm{~g}$ $\mathrm{L}^{-1}$; kombinasi antara ekstrak daun sirsak dan tembakau $150 \mathrm{~g} \mathrm{~L}^{-1}, 300 \mathrm{~g} \mathrm{~L}^{-1}, 450 \mathrm{~g} \mathrm{~L}^{-1}$. Hasil yang didapat menunjukkan bahwa konsentrasi insektisida nabati mempengaruhi pertumbuhan tanaman. Hal ini ditunjukkan dengan peningkatan pada beberapa parameter pertumbuhan. Pertumbuhan paling signifikan terjadi pada perlakuan kombinasi ekstrak daun sirsak dan daun tembakau dengan konsentrasi $450 \mathrm{~g} \mathrm{~L}^{-1}$. Hasil pengukuran tinggi tanaman $59,40 \mathrm{~cm}$, jumlah daun 11,73 lembar, jumlah polong 40,60 buah, jumlah biji 87,16 butir, berat biji $11,04 \mathrm{~g}$, dan berat $100 \mathrm{biji}$ 16,80 g. Hasil pengamatan intensitas serangan hama kutu putih (Bemisia tabacii), perlakuan yang efektif untuk menekan serangan hama adalah kombinasi daun sirsak dan tembakau dengan konsentrasi $450 \mathrm{~g} \mathrm{~L}^{-1}$ pada pengamatan di umur 84 hari setelah tanam sebesar 36,20\%.
\end{abstract}

Kata kunci: Daun sirsak, insektisida nabati, kedelai, tembakau. 


\section{PENDAHULUAN}

Ada beberapa faktor yang mempengaruhi rendahnya produksi kedelai di Indonesia seperti minimnya lahan untuk bercocok tanam kedelai, rendahnya benih unggul dan tingginya serangan hama. Usaha untuk meningkatkan produksi kedelai dalam upaya memenuhi kebutuhan kedelai Indonesia telah banyak dilakukan pemerintah, baik dengan cara ekstensifikasi maupun intesifikasi (Setyowati, et.al., 2005).

Serangan hama pada tanaman kedelai dapat terjadi sejak tanaman mulai tumbuh hingga menjelang panen. Hal ini karena hubungan antara fenologi tanaman dan pemunculan serangan senantiasa ada sinkronisasi. Hama yang menyerang tanaman kedelai cukup banyak, akan tetapi yang mempunyai arti ekonomi penting antara lain hama Phaedonia inclusa, Plusia chalcites, Longitarsus suturellinus, Etiella zinckenella, Riptortus linearis, Nezara viridula, Lamprosema indicata, Spodoptera litura dan Bemisia tabacii. Hama tersebut mampu menimbulkan kerusakan yang berarti pada tanaman dan menimbulkan keruskan signifikan (Sidabutar, 2017). Prayogo dan Suharsono (2005) menambahkan bahwa di Indonesia terdapat empat jenis hama daun yakni kumbang daun ( $P$. inclusa), penggulung daun ( $L$. indicata), ulat jengkal (C. chalcites), dan ulat grayak (S. litura) serta hama kutu daun (Bemisia tabacii Genn).

Alternatif pengendalian yang dapat dilakukan untuk mengata si masalah tersebut adalah dengan memanfaatkan berbagai senyawa kimia alami yang berasal dari tumbuhan. Pemanfaatan insektisida nabati selain dapat mengurangi dampak pencemaran lingkungan, bahannya mudah didapat, dan harganya relatif lebih murah apabila dibandingkan dengan pestisida kimia (Untung, 1996; Sudarmo, 2005). Pemanfaatan bahan tumbuhan bisa mengurangi bahaya untuk kesehatan manusia dan ternak dan pengurangan biaya produksi untuk penggunaan pestisida kimia (Sudarmo, 2005).

Jenis tumbuhan yang dapat dijadikan pestisida nabati antara lain adalah tanaman sirsak dan tembakau. Daun sirsak (Annona muricata L.) memiliki senyawa kimia seperti flavonoid, saponin, tanin, glikosida, annonain, dan senyawa lainnya yang diketahui bisa bertindak sebagai antifeedant, racun kontak dan racun perut bagi beberapa hama tanaman (Julaily \& Rima Setyawati, 2013)

Pada daun tembakau (Nicotiana tabacum, L.) mempunyai karakteristik rasa pahit mengandung alkaloid dan terpen, berbau busuk dan berasa agak pedas. Tembakau jarang diserang oleh hama sehingga banyak digunakan sebagai ekstrak pestisida nabati dalam pertanian organik (Hasyim, et al., 2010).(Hasyim et al., 2010) Daun tembakau mengandung racun sehingga dapat digunakan untuk bahan pestisida pembasmi hama tanaman (Fitri dan Migunani, 2014). (Fitri \& Migunani, 2014) Penelitian ini bertujuan untuk mengkaji konsentrasi insektisida nabati terhadap pertumbuhan dan hasil pada tanaman kedelai (Glycine max [L] Merill.) varietas Anjasmoro.

\section{BAHAN DAN METODE}

Penelitian lapang dilaksanakan di Desa Getas, Kecamatan Wonosalam, Kabupaten Demak, Jawa Tengah dengan ketinggian tempat $100 \mathrm{~m}$ dpl dan jenis tanah gromosol kelabu tua. Pelaksanaan penelitian Juli 2020 sampai dengan Oktober 2020.

Rancangan yang digunakan adalah Rancangan Acak Kelompok Lengkap (RAKL) dengan faktor tunggal, terdiri dari 9 macam perlakuan dan 1 kontrol, ulangan sebanyak 3 kali sehingga diperoleh 30 unit percobaan. Adapun macam perlakuannya yaitu: A0: Kontrol (tanpa perlakuan), B1: ekstrak daun tembakau konsentrasi $150 \mathrm{~g} \mathrm{~L}^{-1}, \mathrm{~B} 2$ : ekstrak daun tembakau konsentrasi $300 \mathrm{~g} \mathrm{~L}^{-1}$, B3: ekstrak daun tembakau konsentrasi $450 \mathrm{~g} \mathrm{~L}^{-1}, \mathrm{C} 1$ : ekstrak daun sirsak konsentrasi $150 \mathrm{~g} \mathrm{~L}^{-1}, \mathrm{C} 2$ : ekstrak daun sirsak konsentrasi $300 \mathrm{~g} \mathrm{~L}^{-1}, \mathrm{C} 3$ : ekstrak daun sirsak konsentrasi $450 \mathrm{~g} \mathrm{~L}^{-1}$, D1: ekstrak kombinasi daun tembakau dan daun sirsak konsentrasi $150 \mathrm{~g} \mathrm{~L}^{-1}$, D2: ekstrak kombinasi daun tembakau dan daun sirsak konsentrasi $300 \mathrm{~g} \mathrm{~L}^{-1}$, D3: ekstrak kombinasi daun tembakau dan daun sirsak konsentrasi $450 \mathrm{~g} \mathrm{~L}^{-1}$.

Pada penelitian ini dibuat 30 petakan dengan ukuran per petak $1,9 \mathrm{~m} \times 0,9 \mathrm{~m}$, yang terdiri dari 3 blok dengan arah tegak lurus. Jarak antar petak $0,3 \mathrm{~m}$ dan jarak antar blok $0,4 \mathrm{~m}$ sekaligus berfungsi sebagai saluran drainase. Penanaman dilakukan dengan menggunakan tugal sedalam $2 \mathrm{~cm}$, dengan jarak tanam $40 \mathrm{~cm} \times 20 \mathrm{~cm}$, Tiap lubang tanam dimasukkan benih kedelai sebanyak 3 butir lalu ditutup dengan tanah dan 2 minggu setelah tanam ditinggalkan 2 tanaman.

Tanaman kedelai yang sudah berumur 14 Hari Setelah Tanam (HST) diaplikasi dengan insektisida nabati dari ekstrak daun sirsak dan tembakau sesuai perlakuan. Caranya dengan menyemprotkan pada semua bagian tanaman, menggunakan handsprayer. Penyemprotan dilakukan sore hari, setiap 2 minggu sekali sampai 2 minggu sebelum panen. 
Pengamatan intensitas serangan hama dilakukan pagi hari, setelah penyemprotan. Pengamatan terhadap pertumbuhan dan hasil panen dibuat tabulasi dan histogram. Data dianalisis dengan Analisis Varian (Anova), jika berbeda nyata kemudian data diuji dengan uji Duncan pada taraf $5 \%$ untuk membedakan rerata antar perlakuan.

\section{HASIL DAN PEMBAHASAN}

\subsection{Pertumbuhan Tinggi Tanaman Kedelai}

Tinggi tanaman merupakan parameter pertumbuhan tanaman kedelai. Pertumbuhan adalah suatu proses bertambahnya ukuran pada tanaman, contohnya pertambahan panjang batang. Menurut Irdiani et al. (2002) pertumbuhan tanaman adalah proses bertambahnya ukuran dari suatu organisme mencerminkan bertambahnya protoplasma. Penambahan ini disebabkan oleh bertambahnya ukuran organ tanaman seperti tinggi tanaman sebagai akibat dari metabolisme tanaman yang dipengaruhi oleh faktor lingkungan di daerah penanaman seperti air, sinar matahari dan nutrisi dalam tanah.

Hasil ANOVA (Analysis of variance) pada taraf $5 \%$ menunjukkan adanya pengaruh pada tinggi tanaman kedelai. Pada perlakuan D3 berpengaruh nyata terhadap tinggi tanaman kedelai sedangkan pada perlakuan $\mathrm{C} 3$ tidak berpengaruh nyata terhadap tinggi tanaman kedelai. Pada perlakuan ekstrak tembakau semua konsentrasi menunjukkan data yang cenderung meningkat namun, tidak menunjukkan pengaruh yang nyata. Pada perlakuan ekstrak sirsak semua konsentrasi tidak menunjukkan pengaruh yang nyata terhadap tinggi tanaman kedelai. Sedangkan kombinasi antara daun tembakau dan sirsak semua konsentrasi menunjukkan data yang cenderung meningkat dan menunjukkan pengaruh yang nyata terhadap tinggi tanaman kedelai.

Hasil pengamatan tinggi tanaman kedelai disajikan pada Tabel 1. Tinggi tanaman kedelai pada umur 56 HST tertinggi pada perlakuan D3 $(59,40$ $\mathrm{cm})$ yang berbeda nyata dengan kontrol A0 $(50,53$ $\mathrm{cm})$. Kombinasi antara daun sirsak dan tembakau dengan konsentrasi $450 \mathrm{~g} \mathrm{~L}^{-1}$ (D3) mengalami peningkatan dari $50,53 \mathrm{~cm} /$ tanaman (kontrol) menjadi $59,40 \mathrm{~cm} /$ tanaman. Pada perlakuan kontrol, tinggi tanaman paling rendah karena unsur hara dan mineral yang dibutuhkan untuk pertumbuhan kurang mencukupi serta tidak diberi perlakuan untuk mencegah perkembangbiakan hama. Pada perlakuan (B3) daun tembakau dengan konsentrasi $450 \mathrm{~g} \mathrm{~L}^{-1}$ menunjukkan peningkatan tinggi tanaman dari $50,53 \mathrm{~cm} /$ tanaman (kontrol) menjadi $56,87 \mathrm{~cm} / \operatorname{tanaman}$. Sedikit berbeda dengan perlakuan (C3) daun sirsak konsentrasi $450 \mathrm{~g} \mathrm{~L}^{-1}$ menunjukkan peningkatan yang tidak terlalu tinggi dengan perlakuan lainya.

Dapat dikatakan bahwa penggunaan daun sirsak sebagai insektisida nabati tidak terlalu berpengaruh terhadap tinggi tanaman kedelai. Hal ini kemungkinan disebabkan oleh senyawa aktif yang terkandung pada daun sirsak tidak bekerja secara maksimal. Berbeda jika ditambahkan daun tembakau, daun sirsak akan efektif untuk mengendalikan hama.

Tabel 1. Pengaruh Konsentrasi Insektisida Nabati terhadap Tinggi Tanaman dan Jumlah Daun Kedelai.

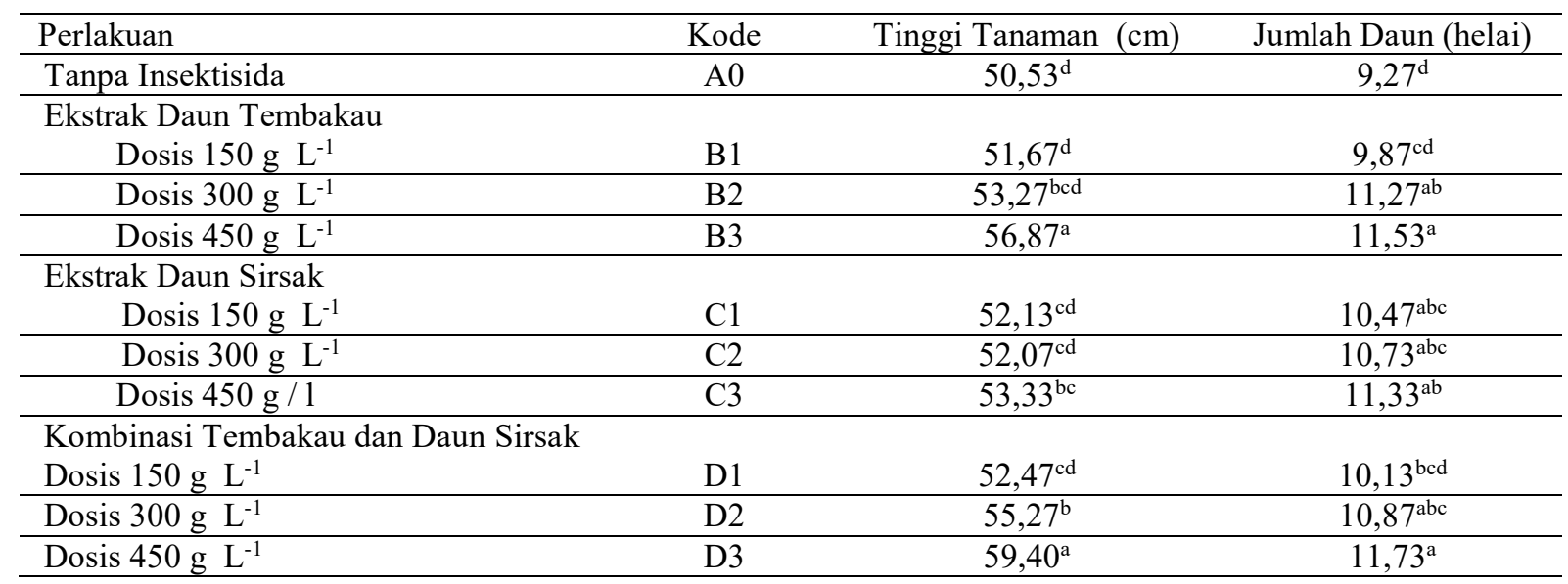

Keterangan: Angka yang diikuti huruf yang sama pada kolom yang sama menunjukkan pengaruh yang tidak berbeda nyata antar perlakuan berdasarkan uji Duncan (DMRT) pada taraf 5\%. 


\subsection{Jumlah Daun}

Jumlah daun tanaman kedelai menunjukkan pertambahan setiap minggunya. Daun kedelai berbentuk tri foliat atau daun majenuk beranak daun tiga. Hasil pengamatan dapat terlihat dari Tabel. 1 yang menunjukkan bahwa daun kedelai pada semua jenis perlakuan berkisar antara 9-12 helai. Tanaman yang dibiarkan atau tidak diberi perlakuan insektisida nabati menghasilkan jumlah daun paling sedikit. Secara umum tanaman yang disemprot insektisida nabati lebih banyak jumlahnya dari pada perlakuan tanpa insekstisida.Pada perlakuan dengan pemberian 3 macam insektisida dengan 3 dosis yang berbeda, hasil daunnya lebih banyak. Hasil tersebut menunjukkan bahwa perlakuan dengan semua konsentrasi berpengaruh terhadap jumlah daun tanaman kedelai varietas Anjasmoro.

Pada perlakuan ekstrak kombinasi antara daun tembakau dan daun sirsak dengan konsentrasi 450 $\mathrm{g} \mathrm{L}^{-1}$ (D3) menunjukkan pengaruh yang nyata terhadap jumlah daun tanaman kedelai. Berdasarkan data yang diperoleh pada perlakuan D3 jumlah daun 11,73. Pada perlakuan ekstrak sirsak pada konsentrasi $450 \mathrm{~g} \mathrm{~L}^{-1}$ menunjukkan bahwa perlakuan tersebut tidak berpengaruh nyata terhadap jumlah daun tanaman kedelai dengan jumlah daun 11,33 helai. Pada perlakuan ekstrak tembakau konsentrasi $450 \mathrm{~g} \mathrm{~L}^{-1}$ (B3) tidak berbeda nyata dengan perlakuan ekstrak kombinasi antara daun tembakau dengan daun sirsak konsentrasi 450 $\mathrm{g} \mathrm{L}^{-1}$. artinya jumlah daun dari kedua perlakuan tersebut relatif sama. Tanaman kedelai yang subur ditentukan oleh jumlah daun dan kondisi perakaran dengan banyak nodul atau bintil akar (Hindersah et al., 2020).(Hindersah et al., 2018)

\section{Jumlah Polong dan Jumlah Biji Per Tanaman}

Berdasarkan hasil ANOVA (Analysis of variance) pada taraf 5\% menunjukkan adanya pengaruh pada jumlah polong dan jumlah biji pertanaman, hal tersebut dapat dilihat pada Gambar 1. Pada perlakuan ekstrak kombinasi antara daun tembakau dan daun sirsak dengan konsentrasi 450 $\mathrm{g} \mathrm{L}^{-1}$ (D3) menunjukkan pengaruh yang nyata terhadap jumlah polong maupun jumlah biji tanaman kedelai, jumlah polong pada perlakuan D3 yaitu 40,60 buah.

Jumlah biji per tanaman berhubungan erat dengan jumlah polong total tiap tanaman. Jumlah biji per tanaman pada perlakuan D3 memiliki jumlah biji lebih tinggi dibandingkan dengan perlakuan lainya. Jumlah biji per tanaman berkorelasi positif dengan jumlah polong tiap tanaman (Dwiputra et al., 2015). Pada perlakuan kombinasi antara sirsak dan tembakau dengan konsentrasi $450 \mathrm{~g} \mathrm{~L}^{-1}$ (D3) menghasilkan jumlah biji 87,16 butir.

Pada pengamatan jumlah polong dengan perlakuan pengendalian hama menggunakan kombinasi daun sirsak dan tembakau dengan konsentrasi $300 \mathrm{~g} \mathrm{~L}^{-1}$ (D2) rata-rata menghasilkan 38,10 buah, sedangkan pada perlakuan ekstrak daun tembakau dengan konsentrasi $300 \mathrm{~g} \mathrm{~L}^{-1}$ (B2) ratarata jumlahnya adalah 34,47 buah polong. Hasil pengamatan jumlah biji per tanaman pada perlakuan

Tabel 2. Pengaruh Insektisida Nabati terhadap Intensitas Serangan Hama Kutu Daun (Bemisia tabaci Genn) pada Tanaman Kedelai (\%).

\begin{tabular}{clllll}
\hline \multirow{2}{*}{ Perlakuan } & \multicolumn{5}{c}{ Rata - rata Intensitas Serangan Hama Kutu Kebul (\% ) } \\
\cline { 2 - 6 } & Umur & Umur & Umur & Umur & Umur \\
\cline { 2 - 6 } & $14 \mathrm{HST}$ & $28 \mathrm{HST}$ & $42 \mathrm{HST}$ & $56 \mathrm{HST}$ & $70 \mathrm{HST}$ \\
\hline A0 ( Kontrol ) & $24,13 \mathrm{abcd}$ & $32,53 \mathrm{a}$ & $52,07 \mathrm{a}$ & $58,53 \mathrm{a}$ & $69,13 \mathrm{ab}$ \\
\hline $\mathrm{B} 1$ & $24,87 \mathrm{ab}$ & $31,27 \mathrm{ab}$ & $45,47 \mathrm{ab}$ & $49,07 \mathrm{abc}$ & $60,00 \mathrm{~cd}$ \\
\hline B2 & $25,87 \mathrm{a}$ & $30,67 \mathrm{ab}$ & $43,40 \mathrm{ab}$ & $45,53 \mathrm{c}$ & $58,53 \mathrm{de}$ \\
\hline B3 & $22,27 \mathrm{bcd}$ & $29,47 \mathrm{~b}$ & $46,40 \mathrm{a}$ & $47,23 \mathrm{bc}$ & $56,47 \mathrm{def}$ \\
\hline C1 & $25,40 \mathrm{a}$ & $31,53 \mathrm{ab}$ & $51,40 \mathrm{a}$ & $56,93 \mathrm{a}$ & $71,60 \mathrm{a}$ \\
\hline C2 & $26,87 \mathrm{a}$ & $33,80 \mathrm{a}$ & $48,40 \mathrm{a}$ & $56,27 \mathrm{ab}$ & $75,07 \mathrm{a}$ \\
\hline C3 & $24,27 \mathrm{abc}$ & $31,27 \mathrm{ab}$ & $49,53 \mathrm{a}$ & $52,27 \mathrm{ab}$ & $63,00 \mathrm{bc}$ \\
\hline D1 & $22,13 \mathrm{cde}$ & $30,73 \mathrm{ab}$ & $38,20 \mathrm{ab}$ & $47,27 \mathrm{bc}$ & $54,13 \mathrm{ef}$ \\
\hline D2 & $21,67 \mathrm{de}$ & $30,00 \mathrm{ab}$ & $37,60 \mathrm{ab}$ & $48,87 \mathrm{abc}$ & $51,00 \mathrm{fg}$ \\
\hline D3 & $19,40 \mathrm{e}$ & $25,47 \mathrm{c}$ & $31,27 \mathrm{~b}$ & $36,40 \mathrm{~d}$ & $48,53 \mathrm{~g}$ \\
\hline
\end{tabular}

Keterangan : Rerata hasil pengamatan intensitas serangan hama kutu putih yang diikuti huruf yang tidak sama pada kolom yang sama menunjukkan pengaruh berbeda tidak nyata antar perlakuan berdasarkan uji Duncan pada taraf $5 \%$. 
kombinasi daun sirsak dan daun tembakau dengan konsentrasi $300 \mathrm{~g} \mathrm{~L}^{-1}$ (D2) rata-ratanya adalah 81,68 biji, sedangkan pada perlakuan ekstrak daun tembakau menghasilkan 70,32 biji/tanaman. Hal ini menunjukkan penggunaan kombinasi ekstrak dua macam daun lebih efektif dibandingkan penggunaan satu macam daun.

\section{Berat Biji Per Tanaman dan Berat 100 Biji}

Pada perlakuan ekstrak kombinasi antara daun tembakau dan daun sirsak dengan konsentrasi 450 $\mathrm{g} \mathrm{L}^{-1}$ (D3) menunjukkan pengaruh yang nyata terhadap berat biji per tanaman kedelai. Berat biji per tanaman pada perlakuan D3 adalah 11,04 g. Hal ini diduga karena perlakuan dengan pemberian insektisida nabati dari kombinasi antara ekstrak sirsak dan tembakau dengan konsentrasi $450 \mathrm{~g} \mathrm{~L}^{-1}$ (D3) memiliki senyawa yang efektif untuk menekan serangan hama. Serangan hama yang terkendali berakibat pada kondisi pertumbuhan buah dan polong yang baik, karena serangan hama selama pembentukan polong muda relatif lebih rendah. Pertumbuhan polong yang tidak diserang hama menghasilkan biji yang utuh.

Perbedaan bobot 100 biji diduga karena sifat genetik tanaman. Soegito \& Arifin (2004) menjelaskan bahwa varietas mempunyai keunggulan genetis yang berbeda-beda sehingga perbedaan pada varietas kedelai yang ditanam memiliki produksi yang berbeda pula, tergantung pada sifat varietas tanaman itu sendiri.

Pada perlakuan D3 menghasilkan berat 100 biji tertinggi dengan perlakuan lainya, pada perlakuan
D3 berat 100 biji adalah 16,80 g (Gambar 2). Menurut Fachruddin (2000) ukuran biji diklasifikasikan menjadi 3 kelas yaitu biji kecil (6-10 g/100 biji), biji sedang (11-12 g/100 biji), dan biji besar (13 g atau lebih/100 biji). Berdasarkan klasifikasi tersebut maka pemberian insektisida dengan kombinasi antara daun sirsak dan daun tembakau berpengaruh terhadap biji tanaman kedelai yang dihasilkan, karena insektisida tersebut dapat menekan serangan hama yang merusak hasil dari tanaman kedelai tersebut.

\section{Intensitas Serangan Hama Kutu Putih pada Tanaman Kedelai}

Pada umumnya serangan hama kutu putih pada pertanaman kedelai meningkat seiring dengan bertambahnya umur tanaman. Tanpa aplikasi insektisida, intensitas serangan cenderung lebih tinggi. Pada perlakuan kombinasi antara ekstrak daun sirsak dan tembakau persentase intensitas serangan hama pada perlakuan kombinasi rata-rata berkisar antara $19,40 \%-36,20 \%$. Tanpa penyemprotan maka intensitas serangan hama kutu putih akan lebih tinggi yaitu rata - rata berkisar $24,13 \%$ - 56,00\% (Tabel 2). Hal ini diduga karena jenis insektisida nabati mempunyai kandungan senyawa bioaktif yang dapat menimbulkan daya kompeten antara jenis insektisida. Senyawa yang terkandung pada masing-masing insektisida adalah saponin, flavanoid, polifenol, tanin, glikosida, annonain, alkaloid, terpen dan senyawa lainnya yang diketahui bisa bertindak sebagai antifeedant, racun kontak dan racun perut bagi beberapa hama tanaman.

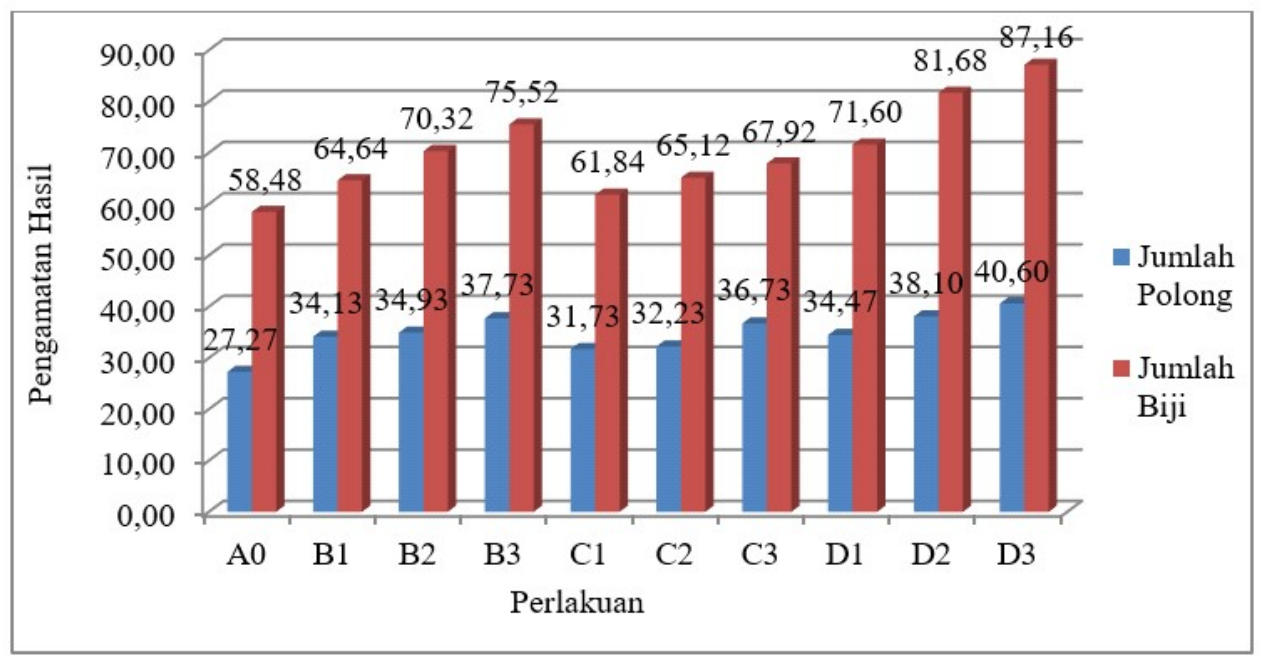

Gambar 1. Diagram Batang Pengaruh Konsentrasi Insektisida Nabati terhadap Jumlah Polong dan Jumlah Biji Tanaman Kedelai. 


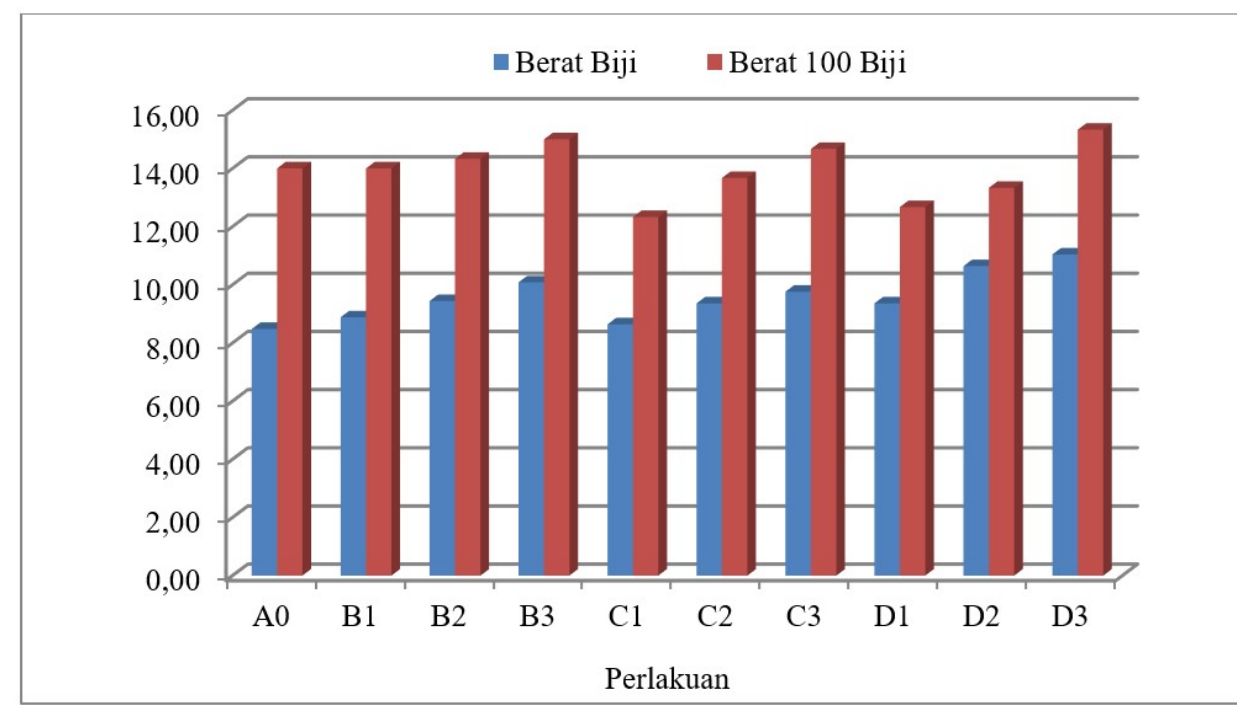

Gambar 2. Diagram Hasil Berat Biji Per Tanaman dan Berat 100 Biji Kedelai Setelah Perlakuan Insektisida Nabati.

Intensitas serangan hama efektif dikendalikan dengan perlakuan kombinasi antara daun sirsak dan daun tembakau. Hal tersebut dapat dilihat pada Tabel 2 bahwa intensitas serangan hama kutu putih tidak begitu tinggi dibandingkan dengan perlakuan lainnya. Penjelasannya: karena senyawa yang terkandung dalam daun sirsak akan lebih efektif jika di kombinasikan dengan senyawa yang terkandung dalam daun tembakau.

Ketiga jenis ekstrak daun sirsak dan tembakau, yaitu ekstrak daun sirsak, daun tembakau dan kombinasi antara daun sirsak dan tembakau memberikan pen-garuh terhadap hama dengan tingkat yang berbeda-beda. Hal ini dikarenakan jenis dan konsentrasi senyawa kimia yang ada di dalamnya pun berbeda. Pengendalian hama kutu kebul yang menyerang tanaman kedelai menggunakan insektisida nabati kombinasi daun sirsak dan tembakau dengan dosis $450 \mathrm{~g} \mathrm{~L}^{-1}$ tampak nyata hasilnya atau tepat. Prinsip 5 tepat meliputi jenis, cara aplikasi, sasaran, waktu dan tepat takaran (Fitri dan Migunani, 2014).

\section{KESIMPULAN}

Berdasarkan hasil penelitian yang dilakukan, maka dapat diambil kesimpulan bahwa pada perlakuan kombinasi ekstrak daun sirsak dan tembakau dengan konsentrasi $450 \mathrm{~g} \mathrm{~L}^{-1}$ dapat mempengaruhi pertumbuhan dan hasil tanaman serta dapat menekan intensitas serangan hama. Hal ini ditunjukkan dengan adanya peningkatan pada pertumbuhan maupun hasil, sedangkan pada serangan hama menunjukkan adanya penurunan serangan yang cukup signifikan. Secara berturutturut untuk parameter tinggi tanaman, jumlah daun, jumlah polong, jumlah biji, berat biji, berat 100 biji adalah 59,40 cm, 11,73 lembar daun, 40,60 polong, 87,16 biji, $11,04 \mathrm{~g}$ dan $16,80 \mathrm{~g}$. Pada pengamatan intensitas serangan hama, perlakuan yang efektif untuk menekan serangan hama adalah kombinasi daun tembakau dan daun sirsak dengan konsentrasi $450 \mathrm{~g} \mathrm{~L}^{-1}$, hasil yang didapat pada pengamatan di umur 84 HST adalah 36,20\%. Aplikasi insektisida berpengaruh positif terhadap pertumbuhan dan hasil, selain itu berpengaruh pula dalam menekan intensitas serangan hama pada tanaman kedelai. Secara umum tanaman kedelai yang diberi perlakuan insektisida menunjukkan kondisi lebih segar dan kuat.

\section{UCAPAN TERIMA KASIH}

Ucapan terimakasih kepada Laboran Fakultas Pertanian UNISRI dan semua pihak yang telah membantu dalam pelaksanaan penelitian ini.

\section{DAFTAR PUSTAKA}

Dwiputra, A.H., Indradewa, D. \& Susila, E.T. (2015). Hubungan komponen hasil dan hasil tiga belas kultivar kedelai (Glycine $\max (\mathrm{L}$.) Merr.). Vegetalika,

Hindersah, R., Risanti, R., Haikal, I., Mahfud, Y., Nurlaeny, N., \& Rachmadi, M. (2020). Effect of Azotobacter Application Method on Yield 
of Soybean (Glycine max (L.) Merill) on Dry Land. Agric, 31(2), 136-145. https:// doi.org/ https://doi.org/ 10.24246/ agric.2019 .v31.i2.p136-145

Irdiani I., Y.Sugito., dan A. Soegianto. 2002. Pengaruh dosis pupuk organik cair dan dosis urea terhadap pertumbuhan dan hasil tanaman Jagung manis. Skripsi. Fakultas Pertanian Unbraw, Malang.

Fitri, M., \& Migunani, S. (2014). Pembuatan Pestisida Menggunakan Tembakau. Pembuatan Pestisida Menggunakan Tembakau, 3(2), 68-71. Jurusan Manajemen Perusahaan, Fakultas D3 Ekonomi, Universitas Islam Indonesia

Hasyim, A., Setiawati, W., Murtiningsih, R., Sofiari, D. E., Penelitian, B., Sayuran, T., \& Parahu, J. T. (2010). Efikasi dan Persistensi Minyak Serai sebagai Biopestisida thd. Helicoverpa armigera. J. Hort, 20(4), 377-386. https:// media.neliti.com/media/publications/85199_ ID-efikasi-dan-persistensi-minyak-seraiseb.pdf

Hindersah, R., Handyman, Z., Indriani, F. N., Suryatmana, P., \& Nurlaeny, N. (2018). Azotobacter population, soil nitrogen and groundnut growth in mercury-contaminated tailing inoculated with Azotobacter. $J$. Degrade. Min. Land Manage, 5 (53), 2502-2458. https://doi.org/10.15243/ jdmlm

Julaily, N., \& Rima Setyawati, T. (2013). Pengendalian Hama pada Tanaman Sawi (Brassica juncea L.) Menggunakan Ekstrak
Daun Pepaya (Carica papaya L.). Jurnal Protobiont, 2(3), 171-175. https:// jurnal.untan.ac.id/index.php/jprb/article/ view/3889

Prayogo,Y. dan Suharsono. 2005. Optimalisasi Pengendalian Hama Pengisap Polong Kedelai (Riptortus linearis) Dengan Cendawan Entomopatogen Verticillium lecanii. Jurnal Litbang Pertanian. Vol. 24. No. 4 : 123-130.

Setyowati, N., U. Nurjanah dan M. Yarni. 2005. Tanggap kedelai kultivar Willis dan Burangrang terhadap pergeseran gulma pada jarak tanam berbeda. Agripura : Jurnal Ilmu-Ilmu Pertanian Fakultas Pertanian Universitas Tanjungpura 1(1):24-27.

Sidabutar, V., Marheni, dan Lubis, L., 2017. Indeks Keanekaragaman Jenis Serangga pada Fase Vegetatif dan Generatif Tanaman Kedelai (Glycine maxMerill) di Lapangan. Jurnal Agroekoteknologi FP USU. Vol.5.No.2, April 2017 (58): 474- 483

Soegito dan Arifin. 2004. Pemurnian dan Perbanyakan Benih Penjenis Kedelai. Malang: Balai Penelitian Tanaman KacangKacangan dan Umbi-Umbian. http:// balitkabi.litbang. pertanian.go.id/

Sudarmo, S. 2005. Pestisida Nabati Pembuatan Dan Pemanfaatanya. Yogyakarta: Kanisius. 58 halaman.

Untung, K. 1996. Pengantar Pengelolaan Hama Terpadu. Yogyakarta: Universitas Gajah Mada Press. 